\title{
CONTRIBUTIONS TO OUR KNOWLEDGE OF SOIL FERTILITY.
}

\author{
No. xiv. The Stimulative Action of Chloroform Retained by \\ THE SOIL.
}

By R. Greig-Smith, D.Sc., Macleay Bacteriologist to the Society.

It appears to be a general rule, that substances which act as protoplasmic poisons also behave as stimulants in minute doses. This is the case with animals and man, with higher plants, and even with single cells such as bacteria. Fred (Centrlb. f. Bakt. 2te Abt. xxxi., 185) showed that bacteria growing in dilute bouillon were favourably influenced by the presence of poisonous chemicals such as copper sulphate, ether, carbon bisulphide, potassium bichromate or salvarsan, when in dilutions of from $1-100,000$ to $1-1,000,000$, according to the kind of microbe.

When a soil is treated with a volatile poison, such as chloroform, and then exposed to the air, the disinfectant is soon dissipated. The effect of the temporary action of the chloroform is shown in an alteration of the soil-constituents, whereby the fertility is increased. Several reasons have been suggested for the change, all depending upon the action of the volatile disinfectant. Some groups of bacteria are destroyed wholly or in part, while others persist, and, under suitable conditions of moisture and temperature, multiply with considerable rapidity. The ammonia-producers are included among the persistent forms. But the soil is altered in some way, for it is able to support a greater bacterial population than formerly.

The hypotheses, that have been advanced to explain the alteration, include that of Russell and the Rothamsted school, who believe that it is brought about by the destruction of the protozoa which normally prey upon the bacteria. Unfortunately for the hypothesis, the addition of the so-called pure cultures of pro- 
tozoa to soil do not bring about a diminution of the bacteria. I have suggested that the bacteria in raw soils limit themselves by the toxic action of their own products of decomposition. Fred thinks the alteration in treated soils is caused by a stimulation of the bacteria by the disinfectant. That the nature of the surviving bacteria may partly explain the rise in bacterial numbers, was shown by an experiment of Russell and Hutchinson, who found that a soil capable of supporting a definite number of bacteria, could accommodate a further number of foreign bacteria.

One of the undoubted effects of the treatment by volatile disinfectants is, that the soil becomes more nutritive. Russell and others have shown that there is an instantaneous production of a small quantity of ammonia. I have suggested that the nutrients are made more available by the translocation of the agricere or fatty substances of the soil, and have shown that the portions of soil, where the agricere gathers, are less nutritive than the other portions. Buddin noted that a disinfectant, such as pyridine, can be attacked and utilised by bacteria. Hutchinson and MacLennan ascribed the growth of bacteria in soils partially sterilised by lime to the chemical action of the lime upon the organic matter of the soil. A number of writers, Störmer, Heinze, Loew and Aso, consider that the treatment brings about a change in the availability of the nitrogen of the soil.

The action of a volatile disinfectant appears to be similar to the simple drying of the soil, although the effect of the disinfectant is more exaggerated. Buddin writes - "It is possible to trace a certain relationship between the action of all the substances used. The intensity of the effects shades off gradually from that of the powerful non-volatile antiseptics through cresol and formaldehyde to the more and less potent volatile antiseptics respectively, till finally the action of merely spreading out the soil in a thin layer is reached."

While the effect of air-drying rapidly wears off, that of the disinfectant persists for some time. The effect of the increased soil-activity, which is intimately associated with the growth of micro-organisms, does not appear to be due to an alteration of 
the physical structure, according to Rahn, but to the nutrients going more easily into solution.

The stimulating effect of a volatile disinfectant, such as chloroform, is not only evident in soil, but also on presumably microbefree, vegetable tissue. For example, the recent work of the Armstrongs shows that many chemicals, including toluene, chloroform, ether, and carbon bisulphide, can bring about an interaction between enzyme and glucoside which does not occur in their absence. The effect is probably caused by an increased permeability of the cell-walls of the tissue by the action of the disinfectant, and the consequent easier migration of the enzyme.

If this applies to a collection of cells, it may also apply to a single cell, such as a microbe, and the action becomes stimulative, as suggested by Fred, and not only may it be stimulative for one bacterial enzyme but for many. Any stimulative action will, however, be restricted to one bacterial cell, and will not influence the progeny of that cell, so that, under the conditions that prevail when a soil is moistened after the removal of the disinfectant, the stimulative action should rapidly disappear. One can imagine an initial but not a prolonged stimulation, such as obtains in treated soils.

It is assumed that all the volatile disinfectant is dissipated when no odour is observable after spreading out the soil to the air, and that none remains in the soil. An appeal to the senses certainly shows that a disinfectant, such as chloroform, has all evaporated. But are we justified in concluding that such is the case? May not some be fixed by the soil-constituents? This question appears to be at the root of the stimulative action of volatile disinfectants, such as chloroform, upon soil, and certain experiments were made to test the validity of the contention.

In testing the persistence of carbon disulphide in treated soil, Moritz and Scherpe* found traces of the decomposition-product, sulphuric acid, up to five months after treatment; while Heinze $\dagger$ found it qualitatively, as carbon disulphide, at the end of a month.

* Centrlbl. f. Bakt., 2te Abt. 12, p.573. †Ibid., 18, p. 62. 
The method of estimating the chloroform, by decomposing it with alcoholic soda and titrating the chloride with silver nitrate, was employed. After a few trials, the following method was adopted. One hundred grams of soil were put into a 300 c.c. flask, and 100 c.c. of methylated spirit containing 5 c.c. of a $10 \%$ alcoholic solution of tartaric acid were added. A Young 12-pear, still-head was attached, and the mixture was distilled. Eighty c.c. were generally obtained in from an hour to an hour and a half. The distillate was treated with 5 c.c. of $15 \%$ soda (one stick of caustic soda, pure by alcohol, to 100 c.c. of water) and 20 c.c. of water, and boiled under an inverted condenser for 10 minutes. Three or four drops of phenolphthalein were then added, and the alkali neutralised with nitric acid $(10 \%$ by volume). After cooling, 1 c.c. of $3 \%$ chromate of potash was added, and the solution was titrated with silver nitrate, 8.535 grams to 1,000 c.c. ( 1 c.c. $=2$ milligrams of chloroform).

In the trial-tests, 11.9 milligrams of chloroform were decomposed with soda, and titrated with 5.95 c.c. of silver nitrate $=11.9$ milligrams of chloroform. One hundred grams of soil, with no chloroform, required at this time $0 \cdot 1$ c.c. of silver nitrate. One hundred grams of soil distilled with alcohol containing 11.9 milligrams of chloroform required 5.9 c.c. silver nitrate $=11 \cdot 8$ milligrams of chloroform. The method is, therefore, fairly accurate.

Experiment i. - A soil containing $8.8 \%$ of moisture was treated overnight with $1.5 \%$ of chloroform, and, in the morning, the soil was spread out on paper. In an hour, all odour of the disinfectant had disappeared. One hundred grams of soil at this stage gave, upon distillation, 13.9 milligrams of chloroform. After a twenty-four hours' exposure to the air, the moisture fell to $1.6 \%$, and $5 \cdot 4$ milligrams of chloroform were recovered from 100 grams of the soil. After a further 24 hours' exposure to the air, 100 grams of the soil yielded $4 \cdot 2$ milligrams of chloroform.

It is apparent that the bulk of the disinfectant is rapidly volatilised upon exposure to the air, and that a small quantity is held persistently. 
Experiment ii.-Six kilograms of soil containing 10.8\% of moisture were sifted, and treated with 60 c.c. of chloroform for 24 hours. The soil was aired for 24 hours, and divided into two parts, one of which was put into a jar with a loose cover; the other was put into an open jar, and the moisture brought up to $10 \%$.

The chloroform was estimated from time to time, due allowance being made for the experimental error by testing an untreated soil in the same manner. The error, using different samples of the same, untreated soil, was equivalent to 0.25 c.c. of silver nitrate, and this has been deducted from the results.

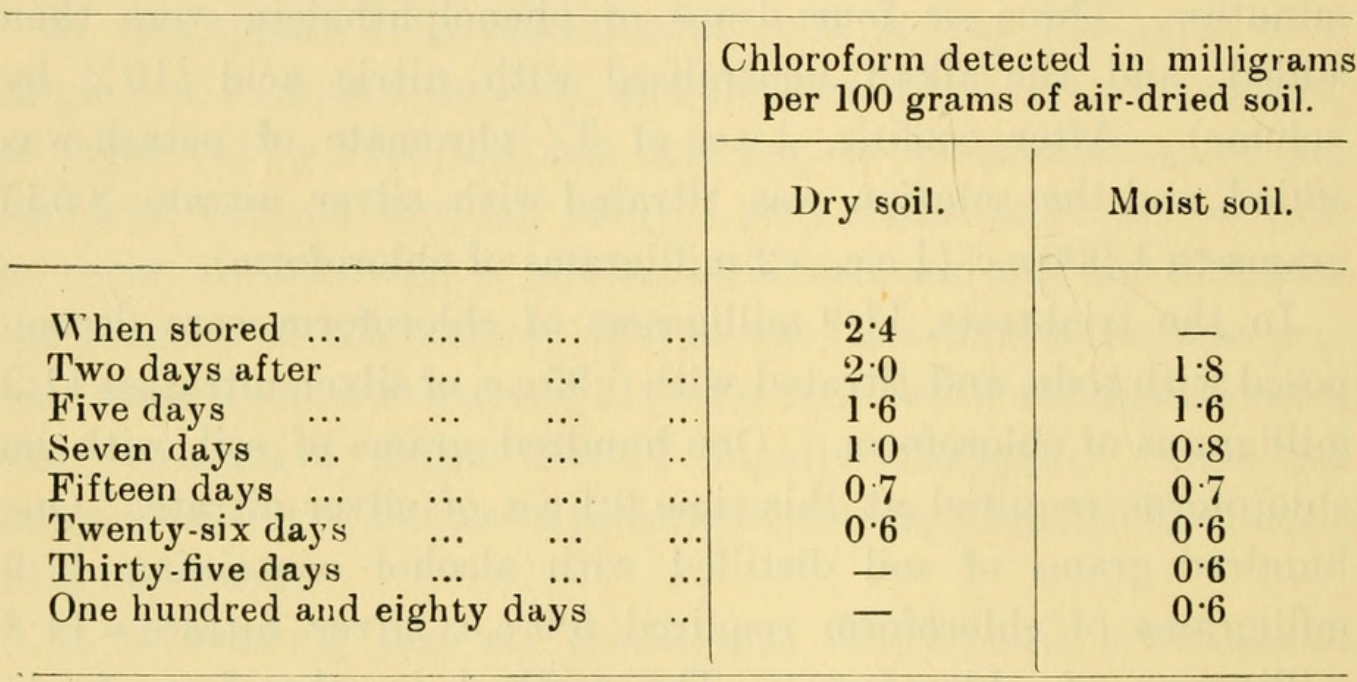

Another sample of air-dried soil was treated with $2 \%$ of chloroform, and after treatment for a day, the disinfectant was aired off for twenty hours. The soil was then stored in a jar with a loose lid, and tested from time to time. As in the previous experiment, due allowance was made for the experimental error.

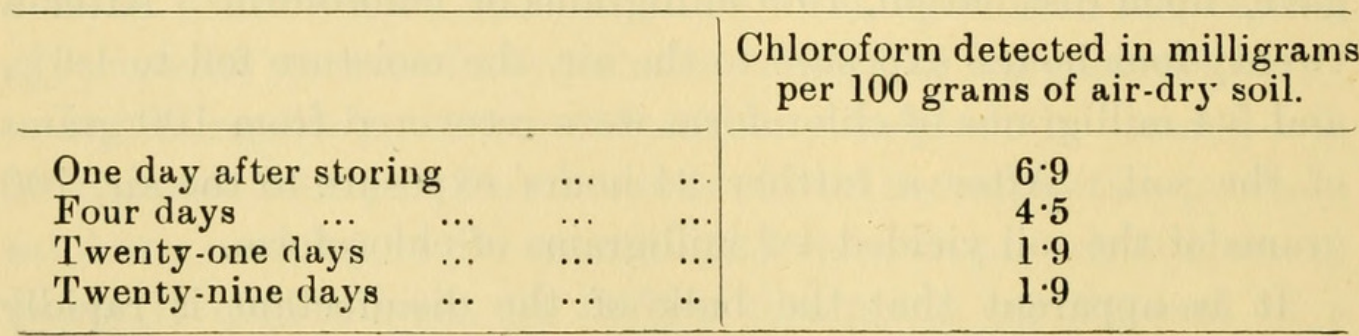

It is clear that there is an appreciable quantity of chloroform retained by the soil. In the case of the damp sample containing 
$8.8 \%$ of moisture, the chloroform was present to the extent of one part in 15,000 of the soil-moisture after a storage-period of 180 days.

Attempts were made to see if there might be any considerable fixation or alteration of the chloroform by the soil. The procedure consisted in chloroforming the soil in a stoppered separating funnel, and, after a lapse of twenty-four hours, in aspirating the free chloroform through alcohol contained in washing-towers. All apparent leakage was guarded against, but, in spite of all precautions, there was a loss of from $20 \%$ to $30 \%$ of the chloroform, not only from soil, but also from sand or cotton-wool, when these were substituted for the soil. The elucidation of the question, therefore, was temporarily abandoned.

Passage of the aspirated air through water did not yield any hydrochloric acid, from which it was concluded that the disinfectant was not altered into carbonyl chloride.

The chlorine-content of the soil is not increased by chloroforming, as was shown by the chloride removable by water being the same, whether the soil had been treated with $1 \%$ or with $2 \%$, or had not been treated.

In a final experiment, a kilogram of garden soil was air-dried, and treated with $2 \%$ of chloroform for four days, aired-off for 24 hours, and the moisture brought up to $10 \%$. It was then stored in a fruit-jar with a loose lid. The chloroform was determined from time to time.

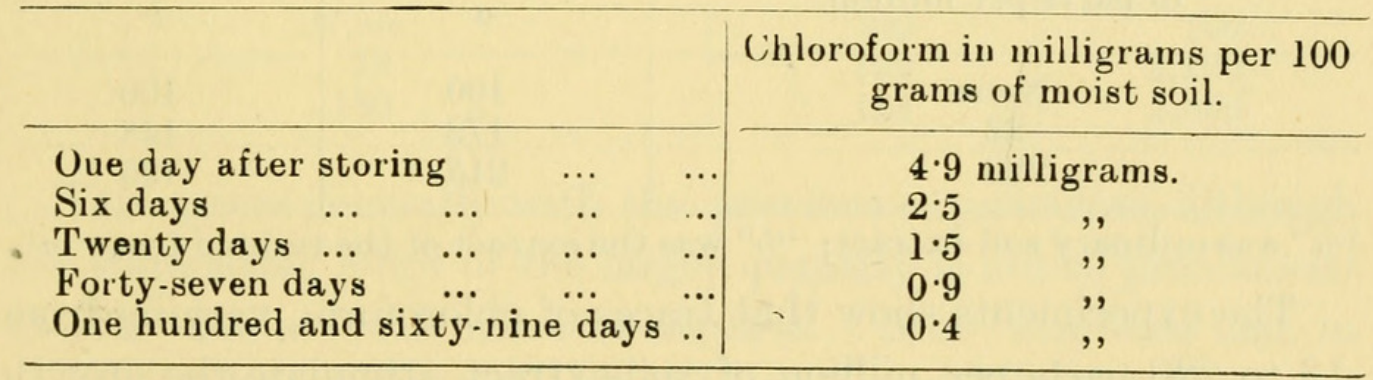

Since traces of chloroform are retained by the soil for some time, these may cause a stimulation of enzymic action and of bacterial growth. Fred showed that such a stimulation was exercised upon certain cultures of pure bacteria when grown in 
dilute bouillon in the presence of several disinfectants. A similar stimulation may also be exercised upon the bacteria that survive the partial sterilisation of soils. As there are so many reasons to account for the increase in soils, it was believed that, if the disinfectant did act as a stimulant, the action could be more clearly shown in porcelain-filtered extracts of soil, treated directly with the disinfectant, and seeded with soil-bacteria.

Extracts of soil were accordingly prepared by shaking a quantity of soil with an equal weight of water, and filtering the extract through water and then porcelain. A volume of the sterile filtrate was treated with one-fifth volume of chloroformwater of two strengths, and seeded with a suspension of Bac. prodigiosus or of soil-bacteria. After an incubation of $22^{\circ}$ for 20 hours, the bacteria were counted by the plate-method.

EХPЕКIM ENTS i. and ii.

\begin{tabular}{c|c}
\hline $\begin{array}{c}\text { Soil-extract containing chloroform } \\
\text { in parts per million. }\end{array}$ & Growth of Bac. prodigiosus. \\
\hline None & 100 \\
13 & 184 \\
130 & 382 \\
\hline None & 100 \\
17 & 109 \\
170 & 164 \\
\hline
\end{tabular}

EXPERIMENTS iii. and iv.

\begin{tabular}{c|c|c}
\hline \multirow{2}{*}{$\begin{array}{c}\text { Soil-extract containing chloroform } \\
\text { in parts per million. }\end{array}$} & \multicolumn{2}{|c}{ Growth of Bac. prodigiosus. } \\
\cline { 2 - 3 } & $a$ & $b$ \\
\hline None & 100 & 100 \\
22 & 172 & 148 \\
220 & 215 & 195 \\
\hline
\end{tabular}

" $a$ " was ordınary soil-extract; " $b$ " was the extract of the residue from " $a$ ".

The experiments show that traces of chloroform, varying from 13 to 220 parts per million of soil-extract, stimulate the growth of Bac. prodigiosus.

Chloroform rapidly deteriorates in aqueous solution, as is well known, but although a portion would disappear during 24 hours' incubation, enough has been left to exert a stimulative action. 
The rate of disappearing was determined in one instance, in which $0 \cdot 122$ gram was shaken up with 100 c.c. of water.

$\begin{array}{lllllll}\text { Chloroform taken by weight } & \ldots & \ldots & \ldots & \ldots & 0 & 122 \\ \text { gram. }\end{array}$

Chloroform determined at once $\quad \ldots \quad \ldots \quad \ldots \quad \ldots \quad 0 \cdot 114$ gram.

Chloroform determined after 20 hours $\quad \ldots \quad 0072$ gram.

The growth of soil-bacteria in chloroformed extracts of soil was then examined. The extracts, after treatment with chloroformwater, were sown with a suspension of bacteria from a soil which had been previously chloroformed and stored in a fairly dry condition (moisture $=4.5 \%$ ).

\section{EXPERIMENT v.}

\begin{tabular}{c|c}
\hline $\begin{array}{c}\text { Soil-extract containing chloroform } \\
\text { in parts per million. }\end{array}$ & Growth of mixed soil-bacteria. \\
\cline { 2 - 3 } None & 100 \\
41 & 144 \\
414 & 79 \\
\hline
\end{tabular}

A stimulation of the growth of the soil-bacteria has occurred in the presence of 41 parts of chloroform per million, while 414 parts have evidently been too much, as they have acted as a toxin.

EXPERIMENT vi.

\begin{tabular}{c|c|c}
\hline \multirow{2}{*}{$\begin{array}{c}\text { Soil.extract containing chloroform } \\
\text { in parts per million. }\end{array}$} & \multicolumn{2}{|c}{ Growth of } \\
\cline { 2 - 3 } & $\begin{array}{c}\text { mixed soil- } \\
\text { bacteria. }\end{array}$ & $\begin{array}{c}\text { Bac. prodigiosus } \\
\text { and } \\
\text { Micr. candidus. }\end{array}$ \\
\hline $\begin{array}{c}\text { None } \\
18\end{array}$ & 100 & 100 \\
180 & 192 & 1,200 \\
123 & 1,850
\end{tabular}

This agrees generally with the previous experiments, although the stimulatiug effect of the larger quantity is not so pronounced as the smaller with the soil-bacteria. Micr. candidus had, in some accidental manner, got into the suspension of Bac. prodigiosus.

The extracts in Experiments i. to vi. had always been nutritive, as was shown by the bacteria, that grew in the unchloroformed extract, being always greater in number than in the water-control 
732 CONTRIBUTIONS TO OUR KNOWLEDGE OF SOIL-FERTILITY, xiv.,

tests made at the same time. In the next experiment, we have a different condition.

Experiment vii.

\begin{tabular}{|c|c|c|}
\hline \multirow{2}{*}{$\begin{array}{l}\text { Soil-extract containing chloroform } \\
\text { in parts per million. }\end{array}$} & \multicolumn{2}{|c|}{ Growth of } \\
\hline & $\begin{array}{l}\text { bacteria from a } \\
\text { raw soil. }\end{array}$ & Bac. prodigiosus. \\
\hline $\begin{array}{l}\text { None } \\
16 \\
165\end{array}$ & $\begin{array}{r}100 \\
106 \\
5\end{array}$ & $\begin{array}{l}100 \\
191 \\
170\end{array}$ \\
\hline
\end{tabular}

This extract was anomalous, inasmuch as it was toxic to the soil-bacteria, and nutritive to Bac. prodigiosus. The great reduction of the bacteria, in the test with 165 parts of chloroform per million, suggests that the toxins of the extract may behave like chloroform, and be stimulative in small doses, and toxic in large doses. In this experiment, the soil-bacteria were obtained from a raw soil, while, in all the other experiments, they were got from a soil which had previously been chloroformed.

Experiment viii.

\begin{tabular}{c|c}
\hline $\begin{array}{c}\text { Soil-extract containing chloroform } \\
\text { in parts per million. }\end{array}$ & Growth of Bac. prodigiosus. \\
\hline None & 100 \\
17 & 100 \\
170 & 137
\end{tabular}

The extract was slightly toxic.

EXPERIMENT ix.

\begin{tabular}{c|c}
$\begin{array}{c}\text { Soil-extract containing chloroform } \\
\text { in parts per million. }\end{array}$ & $\begin{array}{c}\text { Growth of } \\
\text { mixed soil-bacteria. }\end{array}$ \\
\hline None & 100 \\
8 & 58 \\
84 & 3 \\
\hline
\end{tabular}

This soil was strongly toxic, and was again used a week later in the following. 
BY R. GREIG-SMITH.

Experiment $x$.

\begin{tabular}{c|c|c}
\hline \multirow{2}{*}{\begin{tabular}{c|c} 
Soil-extract containing chloroform \\
in parts per million.
\end{tabular}} & \multicolumn{2}{|c}{ Growth of } \\
\cline { 2 - 3 } & $\begin{array}{c}\text { mixed soil- } \\
\text { bacteria. }\end{array}$ & Bac. prodigiosus. \\
\hline None & 100 & 100 \\
10 & 77 & 82 \\
101 & 57 & 52 \\
\hline
\end{tabular}

After the week's storage in the laboratory, the soil did not give so strongly toxic an extract. After still another week, the toxicity had disappeared, and the extract was nutritive.

EXPERIMENT xi.

\begin{tabular}{c|c|c}
\hline \multirow{2}{*}{$\begin{array}{c}\text { Soil-extract containing chloroform } \\
\text { in parts per million. }\end{array}$} & \multicolumn{2}{|c}{ Growth of } \\
\cline { 2 - 3 } & soil-bacteria. & yeasts. \\
\hline None & 100 & 100 \\
7 & 127 & 261 \\
74 & 342 & 203 \\
\hline
\end{tabular}

In the experiment, the yeasts grew upon the same plates with soil-bacteria, and were distinguished by the small size of their colonies. They were very numerous, being in the ratio of about $250: 1$ of the soil-bacteria.

The results of the foregoing experiments show that the chloroform does act as a stimulant in soil-extracts, and we are justified in concluding that it will also act in this manner in soil-moisture Its persistence in the soil after treatment, combined with its action in soil-extracts, argues in favour of the stimulation-theory that the great increase in the bacterial numbers, following treatment of a soil with chloroform, is due in part to the stimulation of the bacteria by small doses of the disinfectant retained by the soil. 


\section{$2 \mathrm{BHL}$ Biodiversity Heritage Library}

Greig-Smith, Robert. 1916. "Contributions to our knowledge of soil fertility.

No. xiv. The stimulative action of chloroform retained by the soil." Proceedings of the Linnean Society of New South Wales 40, 724-733.

https://doi.org/10.5962/bhl.part.18890.

View This Item Online: $\underline{\text { https://www.biodiversitylibrary.org/item/30116 }}$

DOI: https://doi.org/10.5962/bhl.part.18890

Permalink: https://www.biodiversitylibrary.org/partpdf/18890

\section{Holding Institution}

MBLWHOI Library

Sponsored by

MBLWHOI Library

\section{Copyright \& Reuse}

Copyright Status: NOT_IN_COPYRIGHT

This document was created from content at the Biodiversity Heritage Library, the world's largest open access digital library for biodiversity literature and archives. Visit BHL at https://www.biodiversitylibrary.org. 